\title{
Yapısalcı Yöntem ve Uygulama Alanları Structuralism and Its Application
}

\section{Elif TÜFEKÇİ *}

\section{ÖZET}

Yirminci yüzyılın ortalarında etkinlik kazanan yapısalcılık, "gerçeği birbirine bă̆ımlı bir bütün-parça ilişkisi içinde anlama ilkesinden yola çıkan bir öğrenme ve değerlendirme” yaklaşımıdır. Ferdinand de Saussure'ün Genel Dilbilim Dersleri’nde dile getirdiği düşünceler, yalnızca çağdaş dilbilim kuramını değil, göstergebilim ve yapısalcılık akımlarını da derinden etkiler. Başta dilbilimde filizlenip daha sonra tüm insan bilimlerini etkisi altına alan yapısalcılı̆̆ın kaynağında Saussure kuramı yer alır. Saussure'ün yapısal dilbilim alanına katkıları yapısalcı kurama ve yapısalcı uygulamaya da ışık tutar, çağdaş dilbilim alanında getirdiği kavramlar "yapısal”" çalışmaların yöntemsel çıkış noktalarını oluşturur. Makalede, yapısalcı akıma kaynak olan dilbilimin yukarıda sözü edilen evreleri, kavramları ve uygulama yöntemleri incelenecek, yapısalcıllğ etkileyen Saussure sonrası dilbilim okulları ve Rus Biçimselliği ele alındıktan sonra yapısalcılığın uygulama alanları üzerinde durulacaktır.

\begin{abstract}
Structuralism that began to be active in the middle of 20th century is the approach that "stems from the principle of understanding the real in the relationship of the part and the whole". The ideas that are expressed in Ferdinand de Saussure's Course in General Linguistics do not only have deep impact in contemporary linguistics theory but also in semiotics and structuralism. The structuralism thought that first appeared in linguistics but then has begun to affect all human sciences takes its stems from Saussure's theory. The contributions that are done by Saussure in the field of structural linguistics also enlightens the theory and applications of structuralism and the concepts that brought by him to the field of modern linguistics theory constitutes the basic methodological points of "structural" studies. In this article, the above said phases of linguistics that forms the source of structuralism thought will be examined and after the linguistic schools that affected structuralism and Russian Formalism will be handled, the application fields of structuralism will be stressed.
\end{abstract}

Gerçeği tek tek nesneler üzerinden değil nesneler arasındaki ilişkiler yoluyla saptama yöntemi olarak kabul edilen yapısalcılık ile ilgili kaynaklarda akımın genel ve kapsayıcı bir tanımının yapılmasının güçlügü̈nden söz edilir. Yüzeydeki görüntünün altında, derinde yatan kuralların ve yasaların oluşturduğu yapıyı arayan bir yöntem olan yapısalcı yöntem, yapıyı oluşturan birimlerin tek başlarına anlam taşımadıklarını, yapı içinde birbirleriyle olan bağıntılardan anlam kazandıklarını savunur. Yapısalcılıkla ilgili tanımlamalar akımın bir öğreti değil bir yöntem olduğu görüşünde birleşirler:

Yapısalcılık bir yöntemdir, bir öğreti değildir, ancak öğretisel sonuçları çok olmuştur. Bir yöntem olduğundan uygulanabilirliği kısıtlıdır ve verimliliğinden dolayı başka yöntemlerle birleştirilmiştir. $^{l}$

\footnotetext{
* Araştırma Görevlisi, Ankara Üniversitesi Dil ve Tarih-Coğrafya Fakültesi, Tiyatro Bölümü

${ }^{1}$ Jean Piaget. Yapısalcılık. (Ankara: Doruk Yayınları, 1999), s. 129.
} 
Levi-Strauss da aynı biçimde yapısalcılığın bir felsefe olmadığını bir bilimsel yöntem olduğunu savunurken Piaget, Strauss'un bu görüşünü destekler:

Yapısalcılığın göreli olarak uzun bir tarihi vardır ve bundan çıkarılabilecek sonuç, yapısalcılığın belirli bir öğreti veya felsefe olmadığıdır. Eğer böyle olsaydı uzun bir zaman önce göz ardı edilirdi. ${ }^{1}$

Yapısalcı uygulamacıların tümü yapısalcılığı bir felsefe öğretisi değil bilimsel bir yöntem olarak tanımlarlar. Söz konusu yöntemin yönelimlerini Tahsin Yücel altı maddede özetler: incelenmesi;

1. Ele alınan nesnenin "kendi başına ve kendi kendisi için"

2. Nesnenin kendi öğeleri arasındaki bağıntılardan oluşan bir "dizge" olarak ele alınmasi;

3. Söz konusu dizge içinde her zaman işlevi göz önünde bulundurma ve her olguyu bağlı olduğu dizgeye dayandırma zorunluluğunun sonucu olarak, nesnenin artsüremlilik içinde değil, eşsüremlilik içinde ele alınması;

4. Bunun sonucu olarak, köken, gelişim, etkileșim vb. gibi artsüremsel sorunlara ancak nesnenin elden geldiğince eksiksiz bir çözümlemesi yapıldıktan sonra ve bunların da eşsüremsel olgular gibi dizgesel olarak ele alınmalarını sağlayacak yöntemler geliştirildiği ölçüde yer verilmesi;

5. Nesnenin "kendi başına ve kendi kendisi için" incelenmesinin sonucu olarak "doğa ötesel” değil, "özdekçi” bir yaklaşım biçiminde tanımlanmasi;

6. Bu yaklaşımın felsefi, siyasal ya da sanatsal bir öğreti değil, tutarlı bir çözümleme yöntemi oluşturmaya yönelmesi, dolayısıyla erimcilikle hiçbir ilgisi bulunmaması. ${ }^{2}$

Yapısalcı uygulamacılar, herhangi bir incelemenin yapı düzeyinde gerçekleştirilmediği sürece dış görünüşle yetinilip birbiriyle ilişkisiz öğelere takılınacağının kaçınılmaz bir sonuç olacağı noktasında birleşirler. Buradan hareketle, araştırmacının, düzensiz ve karmaşık olaylar yığını altında ezilmemek için yapısalcı yöntemi kullanmasının gereği üzerinde dururlar. Yapısalcı araştırmacı önemliyi önemsizden, belirgini belirsizden ayırır. Yapının iç düzenine yönelmek, dışta kalan etkenleri gerektiğinde yapının gösterdiği yönde değerlendirmek, bağımsız bir bütünle yetinmek yapısalcı araştırmacının temel izleği olmalıdır. Bununla birlikte, nesnenin bir yapı olarak ele alınması gereğini savunan yapısalcı uygulamacılar amaçlarının her şeyi açıklamak olmadığının altını çizerler.

Yapısalcılığın temel kavramları, 20. yüzyılın başında Ferdinand de Saussure'ün Genel Dilbilim Dersleri’nde dilsel olguların incelenmesi üzerine ortaya attığı düşüncelerden hareket alır. Bir kavram olarak yapısalcılığın kurumlaşması dilbilimciler ve yazın incelemecileri tarafından oluşturan

\footnotetext{
${ }^{1}$ J.Piaget. a.g.e. s. 124.

${ }^{2}$ Tahsin Yücel. Yapısalcılık. (İstanbul:Ada Yayınları), s. 10-11.
} 
Prag Dilbilim Okulu'na rastlar. 20. yüzyılın ortasında Claude-Levi Strauss'un yapısalcılık yöntemini sosyal antropoloji alanındaki çalışmalarına uygulamasının da etkisiyle yüzyılın yarısında yapısalcılık, batı ülkelerinin hemen hepsinde tartışma gündemi yaratan bir akıma dönüşür. ${ }^{1}$

Dilbilimin Saussure ile başlayan bilimsel dönemi üç temel aşama geçirir: Saussure ve Amerikalı dilbilimci E. Sapir'in başını çektiği, dilin eşzamanlı boyutta incelenmesini savunan, yüzey yapıyla ilgilenen evre birinci evre olarak kabul edilir. Bu evre, belirgin dilsel yapıları tamamlamak üzerine yoğunlaşır. Saussure temel dilsel birim olarak göstergeyi (signe), Sapir ise sembolü (symbole) kabul eder. Aynı zamanda dizimler (syntagmes) ve dizinler (paradigmes) gibi daha büyük birimler üzerine de çalışırlar. Temel dilsel birimlerin çözümlenmesi ve dil göstergesini oluşturan en küçük birimlerin betimlenmesi Saussure ve Sapir'in izleyicilerinden olan, Prag Dilbilim Çevresi’ni kuran Troubetzkoy ve Jakobson tarafindan sürdürülür. Daha sonra, göstergenin, anlambirim (moneme) ve sözcükbirim (lexeme) ya da biçimbirim (morpheme) gibi düzeyleri Andre Martinet tarafindan ortaya konur. Amerikalı dilbilimciler ise dilin dizimsel ve sözdizimsel çizgisel ekseni üzerinde göstergeler arasındaki bağıntıları incelerler. Bu çalışmalar için Bloomfield, Harris ve Avrupalı dilbilimcilerden Benveniste ile Tesniere'in adları anılır. Sözü edilen birinci evrenin temsilcileri çalışmalarını bir gerçekten üretilmiş sözlü ya da yazılı sözceler bütününden hareketle yaparlar. Bu evre klasik yapısalcılık, işlevsel dilbilim ya da dağılımsal dilbilim gibi adlarla anılır.Yüzey yapı (structure de surface) ya da derin yapı (structure profonde) kurallarına ilişkin varsayımların oluşturulmasıyla birlikte dilbilim kuramlarının ikinci evresi başlar. L. Hjelmslev'in çalışmaları bu evredeki ilk adımlar olarak kabul edilse de derin yapıların incelemesi en açık ifadesini Noam Chomsky'nin üreticidönüşümsel dilbilgisi çalışmalarında bulur. Temel dilsel birim olarak tümceyi kabul eden Chomsky, Descartes ve Port-Royal'in çalışmalarından esinlenerek bir yandan dizimsel yapılarda (structures syntagmatiques) anlamın ortaya çıkışını, bir yandan da derin yapıları yüzey yapılara dönüştüren mekanizmayı inceler.Dilin üçüncü evresini ise tümce düzeyinden daha büyük dilsel birimlerin incelenmesi belirler. Bu noktada dilbilim, üretilen sözceler dizisiyle, bir başka ifade ile söylemle (discours) ilgilenir. Gündelik dilin de edebiyat dili kadar önem taşıdığı üçüncü evrede dilin betimlenmesi derin yapıdan yüzey yapıya kadar devam eden çeşitli düzeylerin ayrımını içerir. ${ }^{2}$

20. yüzyıl dilbilimcileri Saussure devriminin etkisiyle güçlü ve etkin kuramlar, kapsamlı ve tanıtlayıcı uygulamalar ortaya koyarlar. Dilbilim böylece çeşitli bilimlerin kesişme noktası olarak insan bilimleri arasındaki yerini alır. Saussure sonrası dilbilimin genel çizgisini Saussure'ün, Genel Dilbilim Dersleri’nde ortaya koyduğu dil/söz, artzaman/eşzaman, gösteren/gösterilen, dilsel kendilik/sistem, dizimsel/dizisel gibi iç karşıtlıklar üzerinden bir uzlaşı kurmaya yönelik çalışmalar

\footnotetext{
${ }^{1}$ Ayşegül Yüksel. Yapısalcılık ve Bir Uygulama. ( Ankara: Gündoğan Yayınları, 1995 ), s. 30.

${ }^{2}$ Zeynel Kıran. Dilbilim Akımları. (Ankara: Onur Yayınları, 1996), s. 23.
} 
oluşturur. ${ }^{1}$ Dilbilim tarihçileri 20. yüzyıl dilbiliminin Saussure'den kaynaklandığı konusunda hemfikirdirler. A. Meillet, G. Guillaume, E. Benveniste gibi belirli bir akıma bağlı kalmadan çalışmış dilbilimciler dışında Avrupa dilbiliminde iki büyük eğilimden söz edilir: Prag Okulu ve Kopenhag Okulu.

20. yüzyıl dilbilim akımlarının dil konusunda ortak noktasını, dilin yapısal özelliği üzerinde durmaları belirler. Sistem ya da yapının öğeye bir başka ifadeyle bütünün parçaya üstünlüğü 20. yüzyıl dilbilim akımlarının ortak çıkış noktalarıdır. Akımlardan hiçbiri sadece fiziksel özelliklere başvurarak ögeleri tek başına tanımlamayı denemezler; tüm dilbilim okulları dili bir yapı, bir sistem olarak kabul ederler. Buradan hareketle bir dilin tümcelerinin değerinin tek tek öğelerle değil, bu öğelerin karşılıklı ilişkileri içinde ortaya çıktığını vurgularlar. Saussure söz konusu düşünceyi şöyle özetler:

Bir öğeyi yalnız belli bir kavramın birleşimi gibi ele almak yanlış olur. Öğeyi bu yoldan tanımlamak, onu parçası olduğu sistemden ayırmak demektir. $\mathrm{Bu}$, öğelerle başlayıp bunları toplayarak sistemi yaratabileceğimizi sanmak olur. Oysa, tam tersine dayanışık bütünden yola çıkarak bu bütünün kapsadığı öğeleri çözümleme yoluyla elde etmek gerekir. ${ }^{2}$

Saussure'ün yukarıda alıntılanan görüşü yapısalcılığın çıkış noktasını oluşturur.

Rus Biçimselliği, yapısal dilbilim ve Prag Okulu'ndan sonra yapısalcılığın önemli kaynaklarından üçüncüsü olarak kabul edilir. 1915-1930 yılları arasında Moskova ve Petersburg'da etkinlik gösteren bir araştırmacılar topluluğu üyelerinin çeşitli metin türlerine ilişkin ortaya attı̆̆ ilkeler yalnızca yapısalcılığın temel kaynaklarından biri olmakla kalmaz, yazınbilim ve göstergebilimde kullanılan kavram ve yöntemlerin de temelini oluşturur. 1915 yılında kurulan Prag Dilbilim Okulu ve 1916 yılında Petersburg'da kurulan Opoyaz ile birlikte yürütülen çalışmalar, bu görüşe karşı çıkan çevrelerce biçimcilik olarak adlandırılır ancak bu adlandırma eleştirel bir bakış açısına işaret etmekle birlikte söz konusu araştırmacıların çalışmalarını tanımlayan bir terim halini alır.

19. yüzyıl yazın incelemelerinin ve eleştirisinin esere dönük olmayan tavrı Rus Biçimcilerinin ilk eleştiri noktası olur. Sanatı duygu anlatımı olarak algılayan, sanatçıyı merkeze yerleştiren ya da sanatı açıklamak için tarihe, sosyolojiye, politikaya başvuran incelemeleri reddederken, eserden hareket etmeyi amaçlarlar. Her şeyden önce yazını diğer türlerden ayıran biçimsel özelliğin cevabı bulunmalıdır. Buradan hareketle yazını diğer inceleme türlerinden ayrı bir yönteme dayandırmayı hedeflerler. Onlara göre yazın, bir inceleme konusu olarak ele alınmalı ve bilimsel ilkeler bütünüyle değerlendirilmelidir. Yazını inceleyecek olan bilim ya da yöntem de özerk olmalıdır. Bir başka ifadeyle, yazın, felsefe, dinbilim, estetik ya da toplumsal etkenlerle açımlanmamalı, doğrudan yazına yönelik olarak düzenlenmiş bilimsel nitelikli ilkelerle ele alınmalıdır. Yazını ve yazın bilimini özerk kabul eden Rus biçimcileri yazın biliminin asıl konusunun yazın değil yazınsallık olgusu olduğunu

\footnotetext{
${ }^{1}$ Mehmet Rifat. Dilbilim ve Göstergebilim Cağgas Kuramları. (İstanbul: Düzlem Yayınları, 1990), s.8.

${ }^{2}$ Ferdinand de Saussure. Genel Dilbilim Dersleri. Çev.: Berke Vardar. (İstanbul: Multilingual Yayınları, 1998) s. 166.
} 
vurgular. ${ }^{1}$ Söz konusu yaklaşım, Rus Biçimcilerinin yazın metinlerini, yazarların yaşam öyküleriyle, toplumsal yada ruhsal gerekçelerle değil, kendi iç yapılarındaki ilişkilerle, oluşum teknikleriyle açıklamaya çalıştıkları anlamına gelir. Bir yapıtı yazınsal kılan özelliklerin araştırılması, bir çok dil düzeyinin ve bir çok metin düzeyinin ayırt edilmesi gereğini doğurur. Bu noktada Rus Biçimcileri, şiirsel dil ile gündelik dil ayrımının en temel ayrım olduğu görüşünde birleşirler. Dış dünyanın, nesnelere, davranış ya da düşünüş biçimlerine bakarak kanıksandığını iddia eden biçimciler, şiirin söz konusu kanıksamayı sarsarak, nesneleri, davranışları, düşünceleri ve duyguları taze bir bakışla yeniden görmeyi, yeniden algılamayı sağladığını söylerler. Bir başka ifadeyle Rus Biçimcileri yazınsallığın özünü alışkanlığı kırmakta görürler ve metnin bu söz konusu alışkanlıkları kırmayı nasıl sağladığı üzerinde dururlar. Gündelik dilin, bildirişime, betimlemeye yarayan bir araç olarak kullanılırken bilincine varılmaz. Gündelik dil cam gibidir; onu değil onun aracılığıyla işaret ettikleri algılanır. Oysa şiir dili şairin camı bükmesi, bozması, yeni bir düzene sokmasıyla şaşırtıcı bir başkalık yaratır. Bu başkalık insanı silkeleyen, uyandıran ve dile getirilen her ne ise ona yeni bir gözle baktıran bir biçim oluşturur. ${ }^{2}$ Rus Biçimcileri şairin gerçeklik karşısındaki tutumunu değil, dil karşısındaki tutumunu önemserler. Ancak, Rus Biçimciler için dış dünyanın taze bir biçimde algılanması ikinci derecede bir sorundur. Yazınsallık metnin, dış dünya ile ilintisinde değil, dilin kurallarının kırılmasıyla, yeni düzenlenişleriyle ilgili biçimsel sorunlarda yatar. Dış dünya, duygular ya da düşünceler Rus Biçimcilerine göre şiirin ancak malzemesi olabilirler. Dolayısıyla üzerinde durulması gereken yazınsallığı sağlayan nitelikler bir başka ifadeyle, edebiyatın yalnızca biçimsel nitelikleridir.

Rus Biçimcileri, roman ve öykü gibi düzyazı türlerini de yazınsallık bakımından çözümlemeyi amaçlarlar. Onlara göre şiirin alışkanlığı kırma gücü kendi dışında bir şeye işaret etmesinden değil, dilsel düzenlenişinden kaynaklanıyorsa, romanın alışkanlığı kırma gücü de yaşamı yansıtmasından değil, onu özel bir biçimde düzenlemesinden kaynaklanır. Rus Biçimcileri bu durumu açıklamak adına şiirde uyguladıkları ayrıma benzer bir ayrımdan hareket ederler. Şiirde yazınsallık, gündelik dilin değişik bir biçimde düzenlenmesinden kaynaklanır ancak roman dilinin metni ona yazınsallık sağlayan bir özellik değildir. Bu noktada Rus Biçimcileri, gündelik dil/şiir dili karşıtlığı yerine syuzhet/fabula karşıtlığını öne sürerler. Syuzhet, yazarın metinde sunduğu sıra ve biçimdeki olaylar dizisi bir başka ifadeyle olay örgüsü anlamında kullanılır. Fabula ise öykü anlamında kullanılmakla beraber öykü bir anlatı türüne işaret etmez, yazarın düzenlediği olay örgüsünün gerçek yaşamda takip etmesi gereken sıraya göre dizilmiş şekline işaret eder. Berna Moran bu durumu şöyle açımlar:

Diyelim ki romanda konu şöyle bir şey: Bir genç kız $(\mathrm{K})$ ve erkek (E) tanışıyorlar, sonra sevişiyorlar, derken evleniyorlar. Bir süre sonra $\mathrm{E}$ başka bir kadınla ilişki kuruyor ve bu yüzden $\mathrm{K}$ ile kavga ediyor, boşanacak oluyorlar ama sonunda barışıyorlar. Romanı birine özetleyecek olsak olayları

\footnotetext{
${ }^{1}$ Robert Scholes. Structuralism in Literature. (London: Yale University Press, 1974), s. 62.

${ }^{2}$ Berna Moran. Edebiyat Kuramları ve Eleștiri. (İstanbul: İletişism Yayınları, 2000), s. 179.
} 
bu sıraya göre anlatırız. İşte öykü dediğimiz, yaşamdaki sırayı izleyen olaylar zinciridir bu. Ama yazarın bu öyküyü sunuş biçimi hiç de öyle olmayabilir. Belki romana evlilikten sonraki kavgayla başlar, sonra geriye dönerek tanışmalarııı anlatır, derken evlenmeleri olayına atlar ${ }^{1}$.

Yukarıdaki örnekten hareketle, metinde karşılaşılmayan ancak bir çıkarım edimiyle elde edilen olay sırası bir başka ifadeyle öykü, gerçek yaşamdaki gibi zamandizinseldir. Yazar, bu sırayı bozarak yaşamdakine uymayan yapay bir diziye yerleştirir. Rus Biçimcileri, bu noktada romanda yazınsallık özelliğinin söz konusu yapay diziyle birlikte alışkanlığı kırmaktan doğduğunu söylerler. Yazarın zamandizinsel sıraya sadık kaldığı örneklerde de zaman düzeni üzerinde bir oynama söz konusudur. Yazar, kimi olayları özetler, kimilerini daha kısa ya da daha uzun anlatır, kimilerinin ayrıntılarını belirginleştirir. Dolayısıyla, yazar zamandizinsel sıranın dışına çıksın ya da sadık kalsın, zaman düzeninde mutlaka oynama yapar, ayrıca olayların, kişilerin kimin bakış açısından görüleceğini saptarken yapay bir dizge ortaya koyar. Bu dizge alışkanlıkları kırdığı için yazınsallık özelliği taşır.

Lévi-Strauss, akrabalık ilişkileri ile söylenlerin temel yapısını araştırırken ileri sürdüğg̈ yapısal inceleme yöntemi ve dilbilim kaynaklı okuma biçimiyle yapısalcı yöntemi ilk kez dilbilim dışında kalan bir bilim dalında; antropolojide uygular. Bir başka deyişle, dilbilimin insanbilimlerinin tüm dallarına açık olduğu savından yola çıkarak yapısal antropolojiyi yapısalcı ilkeler üzerine temellendirir. Lévi-Strauss, toplumu ya da ekini değişik alanlardan ve değişik düzlemlerden birbirine karşılık veren bir dizgeleşmiş kurallar evreni olarak tanımlar. Çalışmalarında ilk ve temel karşıtlık olarak belirlediği ekin / doğa karşıtlığından başlayarak, yine ikili karşıtlıklara dayalı sınıflandırmalar ve bağıntısal ilişkiler üzerinde durur. Dolayısıyla karşıt, ancak birbirine bağımlılık ilişkisi içinde olan birimler ortaya çıkar. Söz konusu ikili karşıtlıklar farklı düzeylerde şu şekilde sınıflanır: Doğa düzeyinde ikili karşıtlıklardan oluşan ulamlar: kadın / erkek, sağ el / sol el; doğal ve ekinsel olanı ayıran ulamlar: çiğ/pişmiş, doğa/ekin; ekin düzeyinde ikili karşıtlıklardan oluşan ulamlar: yasak / yasak olmayan, din dişı / dinsel. ${ }^{2}$

Lévi-Strauss, insanın kendi ayrıcalıklarını belirlemek adına hayvan ve bitki türlerini simge olarak kullanışından hareketle, bir klanın diğer klanlara göre toplumsal düzeyini belirlemede hayvan topluluklarında görülen ulamların insan toplumlarında da kullanılabilir olduğu görüşündedir. Totemcilik konusuna bu noktadan yaklaşan Lévi-Strauss, kendinden önceki araştırmacıların tersine, benzerliklerin değil, karşıtlıkların üzerinde durur. İki klan arasındaki karşılıklı ilişki, adlarını aldıkları hayvan ulamları arasındaki ilişkinin bir benzeridir:

Sözgelimi, hayvan ulamlarından olan "Kartal" ve "Ayı" adlarından amaç, kartal ve ayı toplumlarının hayvan toplumları düzeyindeki karşılıklı ilişkisini, bu adları alan insan topluluklarında da söz konusu olduğunu belirlemektir. Özetle, A klanı "Ayı" B klanı da "Kartal” adını taşıyorsa, A

\footnotetext{
${ }^{1}$ B. Moran. a.g.e. s. 183.

${ }^{2}$ Ayşegül Yüksel, Yapısalcılık ve Bir Uygulama. (Ankara: Gündoğan Yayınları, 1995), s. 41.
} 
Klanıyla B Klanı arasındaki ilişki, Ayı ile Kartal arasındaki ilişkinin benzeridir:

$$
\text { A : B: : Ay1 : Kartal }
$$

Burada iki karşıtlık dizgesi arasında bir eşyapılılık söz konusudur. ${ }^{1}$

Lévi-Strauss'un yöntemini örneklendiren ilk yapıtı akrabalık ilişkileri üzerine yazdı̆̆ 1 Les structures élémentaires de la parenté (Akrabalı̆̆ın Temel Yapılarl; 1949) olur. Lévi-Strauss, akrabalık ilişkilerine genel bağıntılar dikkate alınmadan tekil olgular halinde bakılmasının birbirinden bağımsız, ayrışık evlenme kurallarıyla karşılaşılmasına neden olacağını söyler. Lévi-Strauss'a göre, bu kadar ayrışık ve dağınık görünen evlilik kurallarının aynı zamanda şaşmayan bir düzen içinde sürdürülmesini bu kuralları ayrışık ulamlar biçiminde sınıflandırarak açıklamak mümkün değildir. Söz konusu kuralları yapısalcı bir bakışla ele alarak toplum içinde kadın dolaşımını sağlamanın değişik biçimleri olarak açıklamak zorunludur.

Lévi-Strauss, bütün toplumlarda görülen yakın akrabalarla cinsel ilişkinin yasaklanmasından yola çıkar. Yakın akrabalarla evlenmenin önlenmesi Lévi-Strauss'a göre yalnızca bir yasaklama olarak kalmaz; yasaklarken düzenleyen bir durum oluşturur. Söz konusu yasak, bir karşılıklık kuralını beraberinde getirir. Lévi-Strauss bu karşılıklık kuralını aşağıdaki biçimde açımlar:

\section{Almayı yadsıdığınız ve size vermeyi yadsıdıkları kadın, sırf bu nedenle sunulan bir kadın oluverir.}

Yukarıdaki örnek erkeğin toplumsal iletişim durumunu ortaya koyar. Erkeğin annesi, kızkardeşi ya da kızıyla evlenmesini yasaklayan kural, erkeği başkalarının annesi, kızkardeşi ya da kızıyla evlenmesini zorunlu kılar. Bir toplumdaki erkek başka bir toplumdaki erkekle ancak kadın değişimi yoluyla ilişki kurduğundan, yakın akraba evliliği erkeğin iletişim kurma durumuna ilişkin bir yarar sağlamaz. Lévi-Strauss söz konusu çözümlemesinde tekil olguları betimlemeyi değil çeşitliliğe rağmen özünde hep aynı kalan yapıya ulaşmayı hedefler. Evlilik dizgesinin de çeşitlemelerinin söz konusu olmasına rağmen Lévi-Strauss'un hedefi çeşitlemelerin aynı olgudan kaynaklandığını ortaya çıkarmaktır.

Lévi-Strauss'un önemli çalışma alanlarından birini de söylenlerin yapısı oluşturur. Söylenlerin anlamsız gibi görülen yinelemelerinin altında yatan temel yapıyı bulmak, bunun içinde insanlığın ortak düşü olarak gördüğü söylenleri yorumlamak gerektiğine inanır. La structure des mythes (Söylenlerin Yapısı; 1955) adlı yapıtında, eşsüremsel okuma adını verdiği bir yöntem kullanır. Bu yöntem, ayırma ve yeniden kurma olmak üzere iki çözümleme aşamasında gerçekleştirilen bir dizi işlemi kapsar. Levi-Strauss, bu yöntemin eksiksiz bir çözümlemeden çok, örnek ve öneri niteliğinde bir çözümleme taslağı olduğunu söyler: Söylenleri tek tek ele alıp açıklamaya çalışmanın bir çıkar yol olmadığını, tersine, onları toplumsal ve ekinsel bağlamları ve başka söylenlerle bağıntıları içinde

\footnotetext{
${ }^{1}$ Ayşegül Yüksel, Yapısalcılık ve Bir Uygulama. (Ankara: Gündoğan Yayınları, 1995), s. 41.
} 
değerlendirmek gerekir. Bu noktada üç temel kuraldan söz eder: Bir söylen hiçbir zaman tek bir düzeyde yorumlanmamalıdır, bir söylen tek başına değil, başka söylenlerle kurduğu bağıntı içinde yorumlanmalıdır ve bir söylen kümesi kendi başına değil, geldikleri toplumun budunbilimi göz önüne alınarak yorumlanmalıdır. ${ }^{2}$

Levi-Strauss ilkel / uygar ayrımına tümüyle karşı çıkar. Dolayısıyla, yaban düşüncenin bilimsel düşünceden nitelikten çok nicelik ve etkinlik açısından ayrıldığını söyler. Yaban düşüncenin temel özellikleri göz önünde bulundurulunca ilkel / uygar ayrımının tüm geçerliliğini yitireceğini savunur. İlkel diye adlandırılan pek çok topluluğun zengin ve tutarlı bitki ya da hayvan sınıflandırmalarına tanıklık etmesi örneği ile bu savını güçlendirir. ${ }^{3}$

Anlatı, zamansal ve nedensel olarak anlamlı bir biçimde bağlantılı bir dizi olayın göstergesel temsili olarak kabul edilir. Geniş anlamıyla, filmler, sahne oyunları, resimli öyküler, romanlar, haber filmleri, günceler, tarih kayıtları birer anlatıdır. Anlatılar, yazılı ya da sözlü dil, görsel imgeler, el kol hareketleri, sahnede canlandırma gibi göstergesel araçların çeşitli biçimleriyle kullanılmasıyla oluşturulabilir. Göstergelerden oluşan her şeyin bir metin olduğu kabul edildiğinde, dilsel, tiyatral, resimsel, sinemasal pek çok türde anlatı metninin varlığından söz edilir. Buna karşılık, anlatı teriminin dar anlamı, her şeyi dışta bırakan bir dilsel olguya işaret eder. Bir sözel metnin ve bir aktarıcının bulunması dar tanımı belirler. Anlatının söz konusu dar tanımı çözümleme alanını sözlü ya da yazılı anlatıyla, yazın incelemelerini de roman, kısa öykü, destansı şiir, balad, fikra gibi yazın türleriyle sınırlar. ${ }^{4}$ Anlatı türünde çözümleme, yapısalcı alanda çalışma yapan araştırmacıların üzerine eğildikleri alanlardan biridir. Yapısalcılar anlatı çözümlemesinde artsüremli bir yaklaşımı değil eşsüremli bir yaklaşımı benimserler. Ayşegül Yüksel yapısalcı araştırmacının söz konusu eşsüremli yaklaşımını şu biçimde açımlar:

Yapısalcı araştırmacı bir anlatıyı incelerken, onun oluşumunu, içerdiği örgelerin tarihçesini ya da bütününü betimlemek yerine, o yapıtın etkin ögelerini bularak hangi anlatımsal sözdizimi kurallarına uyduklarını, nasıl bir bileşim çizelgesi gösterdiklerini, yapısal özelliklerini ve bu yapısal düzenin anlama olan katkısını belirlemeye çalışır. ${ }^{5}$

Yapısalcı araştırmacılar, anlatı çözümlemesinde dilbilimin temel kurallarından hareket ederler. Dil / söz, bağıntılar, karşıtlıklar, gösteren / gösterilen kavramlarından yararlanarak bir anlatı grameri oluşturmayı hedeflerler. Yapısalcı araştırmacıların incelemelerinde birbirlerinden farklı yaklaşımları tek bir anlatı çözümleme yönteminden söz etmeyi imkansız kılar. Bununla birlikte bütün yapısalcı uygulamalarda çözümlenen metin okuma birimlerine ayrılır. Okuma birimlerine ayırma, belirli bir

\footnotetext{
${ }^{1}$ Structualism: An introduction. Edited by: David Robey. (London: Oxford University Press, 1973), s.50.

2 Tahsin Yücel, Yapısalcılık. (İstanbul: Ada Yayınları), s. 63.

${ }^{3}$ Claude Lévi-Strauss, Yaban Düșünce. (İstanbul: Yapı Kredi Yayınları, 2002), s. 35-36.

${ }^{4}$ Susana Onega, José Angel Garcia Landa, Anlatıbilime Giriș. Çev.: Yurdanur Salman, Deniz Hakyemez. (İstanbul: Adam Yayınları, 2002), s.12- 13.

${ }^{5}$ Ayșegül, Yüksel, Yapısalcıllk ve Bir Uygulama. (Ankara: Gündoğan Yayınları, 1995), s. 52.
} 
anlam dağılımını göstermek için kesitleme adı verilen bir işlem üzerine kuruludur. Anlam dağılımının saptanmasında kişilerin, olay örgüsünün, izleklerin oluşturduğu görevsel birimler uzam - zaman düzleminde göz önünde bulundurulur. Söz konusu görevsel birimler arası ilişkiler yapıtın bütünsel anlamını ortaya koyacaktır ve bu ilişkilerin saptanması için eşzamanlı okuma yöntemine başvurulur. ${ }^{1}$

Anlatı türüne ilişkin ilk çözümleme örneği Rus biçimcilerinden Vladimir Propp tarafından yapılır.Göstergebilim, budunbilim, halkbilim ve anlatı çözümlemesi alanlarında yaptığı çalışmalarla Rus Biçimcilerinin önde gelen isimlerinden biri olan Propp'un hem masal incelemeleri alanında hem de anlatı çözümlemesi alanındaki çalışmaları, yöntemsel açıdan bir öncü olması nedeniyle, Saussure'ün Genel Dilbilim Dersleri çalışmasıyla çağdaş dilbilim alanında yarattığı devrime koşut kabul edilir. Masalın Biçimbilimi (Morfologia skazski; 1928), Olağanüstü Masalların Tarihsel Kökenleri (İstoriçeskie korni volșebnoy skaski; 1946), Rus Kahramanlık Destanı (Russkiy geroyçeskiy epos; 1955) adlı çalışmalarının halkbilimin gelişiminde önemli yer tuttuğu kabul edilir. ${ }^{2}$

Propp'un olağanüstü masalların yapısını araştırdığg Masalın Biçimbilimi adlı yapıtı bilim dünyasında en çok öne çıkan çalışması olur. Çağdaş dilbilim ve göstergebilimde göstergelerin değerinin diğer göstergelerle kurdukları bağıntılara göre belirlenmesinden yola çıkan Propp, masalların yapısını irdelemek için çizdiği yolda herhangi bir metnin diğer metinlere göre ayrımsal durumundan hareket eder. Olağanüstü masalların çok renkli ve olağanüstü çeşitliliğine karşıllık görünürdeki söz konusu çeşitlilik altında yatan tek biçimlilikten hareketle; yüzeydeki çeşitliliğin altında binlerce masalın yapısında ortak olabilecek işlevsel birimleri bulmayı hedefler. Bu çalışmayla halk masalının yapısını düzenleyen değişmez yasaları belirlemiş olur. ${ }^{3}$

Propp’un Masalın Biçimbilimi adlı kitabı, masal üzerine daha önce yapılmış olan çalışmaların eleştirildiği "Sorunun Tarihçesi” bölümü ile başlar. Masalın kökenini, doğuşunu ve kaynaklarını araştırmak için önce masalın ne olduğunun bilinmesi gerektiğini savunur. Bir başka ifadeyle, masalların artsüremli bir incelemesinin yapılabilmesinin koşulu öncelikle eşsüremli bir çalışma yapilmasidir ${ }^{4}$ :

Masalın bütün özelliklerinin yapısal incelemesi, masalın tarihsel incelemesinin yapılması için zorunlu bir koşuldur. Bilimsel açıdan kurala uygunlukların incelenmesi, tarihsel açıdan kurala uygunlukların incelenmesini belirler. ${ }^{1}$

Masal incelemeleri konusunda daha önce gerçekleştirilmiş çalışmaların artzamanlı yöntemlerinin eleştirisinden sonra Propp, kendi yöntemini açıkladığı "Yöntem ve Gereç" bölümünde

\footnotetext{
${ }^{1}$ A. Yüksel. a.g.e. s.53.

${ }^{2}$ Robert Scholes. Structuralism in Literature. (London: Yale University Press, 1974), s. 63.

${ }^{3}$ Vladimir Propp. Masalın Biçimbilimi. Çev.: Mehmet Rifat, Sema Rifat. (İstanbul: Om Yayınları, 2001), s. 10.

${ }^{4}$ Propp, Olağanüstü Masalların Tarihsel Kökenleri adlı çalışmasında eşsüremli bir çözümleme yerine artsüremli bir inceleme yapar. Bu çalışmasında masalların tarihsel oluşumlarını, kökenlerini araştııırken, masalları, kendi iç yapılarıyla değil toplumsal bir çevrede oluşumlarıla değerlendirir.
} 
işlevlerin saptanmasına geçer. Anlatı çözümlemesinin temel anahtarı olan işlevi Propp aşağıdaki örneklerle açımlar: götürür.

1. Kral, bir yiğite, bir kartal verir. Kartal, yiğiti, başka bir krallığa

2. Büyükbaba, Suçenko'ya bir at verir. At, Suçenko'yu başka bir krallı̆ga götürür.

3. Bir büyücü, İvan’a bir kayık verir. Kayık, İvan’ı başka bir krallığa götürür.

4. Kraliçe, İvan'a bir yüzük verir. Yüzükten çıkan iriyarı adamlar İvan's başka bir krallığa götürürler.

Burada saydığımız durumlarda, değişmez değerler ile değişken değerlere rastlarız. Değişen, kişi adları ve aynı zamanda kişilerin özel nitelikleridir; değişmeyen ise, kişilerin eylemleri ya da işlevleridir. Buradan, masalın, çoğunlukla, aynı eylemleri değişik kişilere yaptırdığı sonucu çıkarılabilir. Bu da , masalları, kişilerin işlevlerinden kalkarak incelememizi sağlar. ${ }^{2}$

Propp'a göre, işlev kişinin eylemidir ama söz konusu eylem de olay örgüsünün akışı içindeki anlamına göre belirlenir. Kişilerin eylemleri masalların temel bölümleridir; Propp bu eylemleri kişilerin her masalda sürekli değişebilen özelliklerinden soyutlayarak ele alır. Her eylemi anlatının akışı içindeki yerini dikkate alarak belirler. Bu yolla otuz bir işlev saptar:

1. Uzaklaşma,

2. yasaklama,

3. yasağı çiğneme,

4. soruşturma,

5. bilgi toplama,

6. aldatma,

7. suça katılma,

8. kötülük,

9. aracilik,

10. karşıt eylemin başlangıcı,

11. gidiş,

12. bağışcının ilk işlevi,

13. kahramanın tepkisi,

14. büyülü nesnenin alınması,

15. iki krallık arasında yolculuk,
16. çatışma,

17. özel işaret,

18. zafer,

19. giderme,

20. geri dönüş,

21. izleme,

22. yardım,

23. kimliğini gizleyerek gelme,

24. asılsız savlar,

25. güç iş,

26. güç işi yerine getirme,

27. tanınma,

28. ortaya çıkarma,

29. biçim değiş̧tirme,

30. cezalandirma,

\footnotetext{
${ }^{1}$ V. Propp. a.g.e. s. 34

2 V. Propp. a.g.e. s. 38.
} 


\section{1. evlenme. ${ }^{1}$}

Propp'a göre, bütün masallarda söz konusu işlevlerden hepsine birden rastlanmaması masalların olay örgüsündeki ortaya çıkış düzenini sarsmaz; işlevler tüm masallarda aynı sırayı takip ederek ortaya çıkarlar. Kişiler değişik masallarda değişik özelliklere sahip olsalar da eylemlerinin temel yapısı bir başka ifadeyle işlevi aynıdır. Dolayısıyla işlevler adıyla anılan eylemler masalların sürekli var olan öğeleridir; kişilerin özellikleri ne olursa olsun anlatıyı oluşturan işlevlerdir.

Propp, incelediği masallarda, akışın yapılan bir kötülükle başladığını saptar. Söz konusu kötülük belli bir ailede, belli bir çevrede, belli bir eksiklik yaratır. Bir kahraman eksikliği gidermek, kötülüğ̈̈ ortadan kaldırmakla görevlendirilir. Kahramanın gerçekleştirmesi gereken bu zor işinde bazıları ona yardım ederken bazıları da karşı koyar. Kahraman bir iki kez başarısızlığa uğrayarak, sınanarak ve denenerek eksikliği gidermeye çalışır. Görevini gerçekleştirince ödüllendirilir. Propp, genel anlatı örgüsü içinde daha önce saptadığı otuzbir işlevin yedi kişinin eylem alanında dağıldığını belirler: Saldırganın (kötü kişinin) eylem alanı; bağışçının (sağlayıcının) eylem alanı; yardımcının eylem alanı; prensesinin (aranan kişi) ve babasının eylem alanı; gönderenin (görevlendirilenin) eylem alanı; kahramanın eylem alanı; düzmece kahramanın eylem alanı.

Propp'un Masalın Biçimbilimi adlı yapıtında ortaya koyduğu çözümleme yöntemleri hem kuramsal hem de uygulama açısından kendisinden sonra gelen araştırmacılara kaynak oluşturur. Başta Lévi-Strauss olmak üzere Greimas, Barthes, Bremond, Todorov gibi bilim adamları Propp'un belirlediği çözümleme yöntemini değerlendirirler. Özellikle Greimas Propp’un işlev kavramını yeniden yapılandırarak anlatı çözümlemelerinde sözdizim örnekçesinin kalıcı ilkelerini saptar:

Claude Lévi-Strauss, ünlü araştırmacının uygulamada bir takım yanılgılara düştüğünü, çözümlemeyi yeterince geliştirmediğini, biçim düzeyinde kalmayı yeğleyerek içeriği yeterince göz önüne almadığını vurgular. Greimas da incelemede ortaya çıkarılan işlevlerin kimilerinin ötekilerin yinelenmesi olduğunu, dolayısıyla daha da indirgenebileceklerini gösterir. Ama böyle bir yöntemin ilk uygulayıcısı olması bile, Propp'un büyük bir öncü sayılmasına yeter. Anlatıların eklemlenimlerine ilişkin yapısal araştırmaların kökeninde hep Propp'un bu ilk adımını buluruz. ${ }^{2}$

Propp'un Masalın Biçimbilgisi kitabı, anlatı çözümlemelerine bir inceleme örneği olarak kaynak sunmakla kalmaz, aynı zamanda halkbilim alanındaki çalışmaları bilgi toplama ve salt tarihsel boyutla ilgilenme aşamasından masalların yapısını kavrama aşamasına yönlendirir.

Propp, Rus halk masallarının yapısının iki çeşit bileșenden oluştuğunu saptar: Çeșitli kișilerin eylem alanları ve olay örgüsünü oluşturan işlevler. Propp, aynı zamanda işlevlerin masal içindeki sıralamalarının hep aynı olduğunu ve tüm Rus halk masallarının yapıları açısından tek çeşitli olduğunu vurgular. Bu noktada Propp'un halk masallarıla ilgili söz konusu çalışmasıyla Lévi-Strauss'un söylenlerle ilgili çalışması arasındaki farka değinmek gerekir. Propp çözümleme birimi olarak masalı

\footnotetext{
1 Robert Scholes. Structuralism in Literature. (London: Yale University Press, 1974), s. 63 - 64.

2 Tahsin Yücel, Yapısalcılık . (İstanbul: Ada Yayınları), s. 79.
} 
ele arrken, Lévi-Strauss'un çözümleme birimi masallarda yer alan söylenlerdir. Dolayısıyla Propp'un dizimsel yaklaşımına karşılık Lévi-Strauss, dizisel bir yaklaşım sergiler. ${ }^{1}$

Yapısalcı akımın önemli isimlerinden biri de anlatıların çözümlenmesinde bir "anlatı grameri” oluşturmayı hedefleyen Todorov'dur. Rus biçimcilerinin metinlerini Fransızca'ya çevirerek batı ülkelerinde yapısalcı yöntemin gelişmesinde önemli rol oynayan Todorov, uzun yıllar hem Rus Biçimcilerinin hem de Roman Jakobson'un yakın izleyicisi olur. Dilbilgisini örnekçe alarak, anlatıları dilbilgisel ulamlara göre çözümlemeyi hedefler; ortaya attığı yazınbilim anlayışında metni büyük bir tümce olarak değerlendirir. Todorov, anlatı türündeki yapıtların yapısını ortaya çıkarmak için, Boccacio'nun Dekameron Öyküleri adlı çalışmasını, Grammaire du Décaméron (Dekameron'un Dilbilgisi; 1969) yapıtında inceler. Boccacio'nun öykülerinin gramerini saptamayı hedefleyen Todorov, "gramer" kavramını öykülerde kullanılan dilin grameri anlamında değil, öykülerin yüzeyde görünmeyen derinde yatan yapısı anlamında kullanır. Öykülerin derin yapısının dilin yapısına uymasından hareketle dilsel bir terim olan gramer terimini yeğler; aynı amaçla öyküleri çözümlerken dilbilim kategorilerinden faydalanır.

Todorov, incelediği yüz öykünün ortak yapısal özelliklerini saptamak için öykülerin nasıl bir şemaya indirgenebileceğini araştırır:

Genç bir rahibe olan İsabetta sevgilisiyle hücresindedir. Bunu fark eden öteki rahibeler kıskançlığa kapııırlar ve İsabetta’yı cezalandırması için başrahibeyi uyandırmaya giderler. Ama başrahibe de bir papazla yataktadır; hemen dışarı çıkması gerektiği için kendi başlığı yerine papazın donunu kafasına geçirir. İsabetta kiliseye götürülür; başrahibe onu azarlamaya başlayınca, İsabetta başındaki şeyi görür. Bu kanıt herkesin dikkatini çeker, böylece cezadan kurtulur. ${ }^{2}$

Yukarıdaki öykü ve buna benzer öykülerden hareketle Todorov öykülerin olay örgüsünü ortak bir şemaya indirger. Şemada $(\rightarrow)$ işareti iki eylem arasındaki nedenselliği gösterir:

$\mathrm{X}$ bir yasayı çiğniyor.

Y, X'i cezalandırmalıdır.

$\mathrm{X}$ cezadan kurtulmaya çalışıyor.

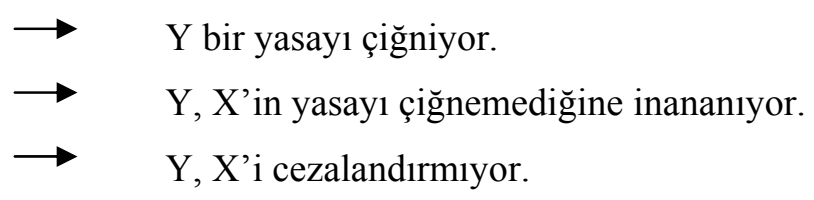

Todorov, yukarıdaki şemanın her bir cümlesini, anlatının daha aza indirgenemeyecek temel birimleri olarak kabul eder. Önerme adını verdiği bu cümlelerin en az bir karakterle onun eyleminden ya da özelliklerinden oluştuğunu söyler. Önermeler, dilsel terimlerle açıklandığında karakterler adlara, karakterlerin eylemleri fiillere, nitelik ve özellikleri ise sıfatlara denk düşer. Bu birimlerin

\footnotetext{
${ }^{1}$ Ayşegül, Yüksel, Yapısalcılık ve Bir Uygulama. (Ankara: Gündoğan Yayınları, 1995), s. 55.

2 Tzvetan Todorov, "Anlatı türünde Yapısal Analiz," Çev.: Bülent Aksoy. Birikim, 2, 4 (HaziranTemmuz 1977), s. 90.
} 
çeşitli biçimlerde bağlanmaları ayrı öyküleri oluşturur. Dolayısıyla Todorov, bir öykünün tüm metnini adların, fiillerin ve sıfatların bağlanmasından oluşan büyütülmüş bir cümleye benzetir.

Karakterlerin niteliklerini, bir başka ifadeyle sıfatları durumlar, iç özellikler ve dış koşullar olarak üç gruba indirgeyen Todorov, olay örgüsü tiplerini saptamak amaciyla eylemleri de üç tür fiil grubu altında toplar. "Durumu değiştirmek", "bir yasayı çiğnemek", "ceza vermek ya da vermemek" başlıkları altında toplanan üç fiil grubundan hareket ederek öykünün kaç çeşit olay örgüsüne ayrılabileceğini ortaya çıkarır. Berna Moran, Todorov’un bu görüşünü şöyle açımlar:

Öykülerin bir kısmı "durum değiștirme", yani "kişilik değiştirme" ile ilgilidir. Örneğin, öykünün başında hasis olan bir karakter, arkadaşının alayları sonucu, bu niteliğini değiştirir ve cömert olur. Bazı öykülerde ise olay örgüsünü belirleyen öteki eylemlerdir ve bundan ötürü, bu öyküler yasalarla, kurallarla ve cezalarla ilgili öyküler olur. Böylece Todorov, eylemlere dayanarak olay örgülerinin çeşitlerini saptayabileceğimizi iddia ediyor. ${ }^{1}$

Todorov'un amacı öykülerin yorumunu yapmak, anlamını açıklamak değil dilsel bakımdan nasıl kurulduklarını açıklamaktır. Bu noktada önemli olan anlatının düzenleniş ilkelerinin belirgin kılınması, yüzeyde görünmeyen derin yapının ortaya çıkarılmasıdır. Öyküler yapısalcı bakışla incelenirken, yüzeyde görünen insan ilişkilerini, duyguları ya da olayları değil tüm anlatı öğelerinin düzenleniş kurallarını belirleyen bir sistemi açıklamak önem kazanır.

Yapısalcı yöntemin tiyatro alanında uygulama çabaları Prag Okulu'nda başlar; okul çevresinde yer alan araştırmacılar yapısalcı çalışmaların tiyatro alanında bir kuram oluşturmasını amaçlarlar. $\mathrm{Bu}$ amaç doğrultusunda öncü nitelik taşıyan çalışma Otakar Zich'in Dramatik Sanatın Estetiği (Estetika Dramatickeho) adlı çalışmasıdır. Söz konusu çalışma, tiyatroyu oluşturan öğeleri kavramsal öğeler ve somut olarak gözlemlenebilen öğeler olarak olarak ikiye ayırmıştır. Benzer bir çalışma Tadeusz Kowsan'ın “Tiyatroda Gösterge” (The Sign in Theatre) adlı çalışmasıdır. Yapısalcı yöntemin tiyatro alanında bir kuram oluşturma çabaları Prag Okulu çevresi dışında Sorbonne Üniversitesi'nden gelir. Üniversitenin profesörlerinden Etienne Souriau "İkiyüzbin Dramatik Durum" (Les deux cent mille situations dramatiques) isimli çalışmasında Propp'un saptadığı yedi görevi hatırlatan altı işlev saptar. Her işlevi astrolojik simgelerle ifade eden Souriau, herhangi bir dramatik metnin derin yapısını bu formüllerle saptanabileceğini savındadır. ${ }^{2}$

Tiyatro alanında yapısalcı yaklaşımı bir tek oyun metni üzerinden gerçekleştirmiş çözümlemelere John Bush Jones’un “Pinter'ın Issız Topraklar Oyununda Belirleyici Yapı Olarak Durallık” ve Sevda Şener'in “Ahmet Kudsi Tecer'in Köşebaşı Adlı Oyunu ve Türk Tiyatrosunun Ayırıcı Özellikleri”" adlı çalışmaları örnek verilebilir. Ayşegül Yüksel'in "Harold Pinter'in Git - Gel Dolap Oyununda Anlam Dizgeleri” ve Vasıf Öngören'in Zengin Mutfağı çözümlemeleri yapısalcı

\footnotetext{
${ }^{1}$ Berna Moran. Edebiyat Kuramları ve Eleștiri. (İstanbul: İletişim Yayınları, 2000), s. 194.

2 Martin, Esslin. Dram Sanatının Alanı. (İstanbul: Yapı Kredi Yayınları, 1996), s. 96.
} 
bakış açısıyla yapılmış çalışmalardır. Ayşegül Yüksel, Melih Cevdet Anday’ın oyunlarını yapısalcı bir yaklaşımla çözümlediği Yapısalcılık ve Bir Uygulama adlı kitabında incelenen oyunların her birini oluşturan birimler, aralarındaki dizisel veya dizimsel bağıntılar içinde eşzamanlı bir yaklaşımla ele almıştır.

Esen Çamurdan, tiyatroda yapısalcı yaklaşımı, Louis Jouvet'in “oyun makineye dönüşen bir düşüncedir” tanımlamasından hareketle makinanın / kurgunun şemasını çıkarmak olarak tanımlar. Makineyi kendi parçalarına ayırma olarak adlandırdı̆̆ı söz konusu işlemin, incelemeciyi yazarın / yönetmenin dizgesine götürdüğünü, kurgusuna ulaştırdığını söyler. Metnin ve / veya sahnenin yapısal kurgusu üstünde durmanın makinanın vidalarını yeniden takmak üzere sökmek olduğunu vurgular:

(...) Yazılı metne veya sahnedeki bir oyuna yapısal yaklaşımda bulunmak, ele alınan yapıta bir tür "kazı yapma" yollarını araştırmaktır. Metnin / sahnenin çeşitli okuma katmanlarını ve anlam örgütlenmesini çözümlemek, göstergelerin işleyişini, plastik malzemenin bir anlatım aracı olarak kullanılmasını saptamak, gözlemlemektir. Yine aynı bağlamda, kişi ve uzam ilişkileri boyutunda, uzamın kullanımı, oyuncu ve nesnelerin seçilmiş olan uzamda dağılımı, seyircinin konumu da gözden kaçırılmaması gereken önemli noktalardır. Bunların değerlendirmesi yazar / yönetmen denklemini ortaya çıkarırken, metnin /sahne denkleminin de altını çizmiş olacaktır." ${ }^{l}$

Yapısalcı yöntemin çıkış noktalarını belirleyen Saussure, her türden göstergenin toplum içindeki işleyiş yasasını inceleyecek bir bilim tasarlamıştır. Göstergebilim olarak tanımlananacak bu bilimin ve Saussure'ün açtığı yolda ilerleyen kuramcılar, gösterge kavramını sadece dil alanına değil, bildirişim dizgesi niteliğindeki birçok alana uygularlar. 1930'lardan sonra tiyatroda göstergebilimsel bir kuram oluşturma çabasına girilmiştir. Bu çaba, tiyatro olgusunu dış etkenlerden uzak tutarak kendi dinamikleri bağlamında ele alacak bir incelenme yöntemi oluşturma isteğinden doğar. Kowzan'ın 1968 yılında yayınlanan "Tiyatroda Gösterge” isimli makalesi tiyatro göstergebilimi açısından büyük önem taşır. Kowzan söz konusu ça1lşmasında sahneye ilişkin on üç gösterge sistemi sayar. Kowzan'ın göstergebilim sistemi, sahnelenmekte olan bir oyundaki tüm göstergeleri dikkate almayışıyla eleştirilse de tiyatronun göstergebilimsel alanını tanımlaması açısından ilk adım sayılır.

Tiyatro göstergebilimi çerçevesinde seyirci, sahneyi oluşturanlar, metin, anlamdırma ve çözümleme kavramları önem kazanır. Çözümleme, gösterimin bir öğesinden diğerine sürekli geçiş yapılabilen bütünün, ince dilimler ya da sonsuz küçük birimler halinde ayrıştırılması, kesilmesi ve parçalara bölünmesi olarak tanımlanabilir. Anlamlandırma kavramıyla birlikte tiyatronun asal elemanlarından biri olan gösteri mekanının yani sahnenin temel özelliği ortaya çıkar: Anlam üretmek. Gerçek yaşamda karşılaşılan önemsiz bir konu ya da olay sahnede gösterge aşamasına yükselir. Boş bir resim çerçevesinin asıldığı duvarın dokusunu belirginleştirmesi, duvardaki çiziklere ya da çatlaklara anlam katması gibi sergilenen her şey gösteri mekanında anlam kazanır. Sahne üzerindeki her nesneye bir anlam yüklenmiş, dikkatler ona çekilmiş bir başka ifadeyle o nesne vurgulanmış olur.

\footnotetext{
${ }^{1}$ Esen Çamurdan. Cağgaș Tiyatro ve Dramaturgi. (İstanbul: MitosBoyut Yayınları, 1996), s. 45 - 46.
} 
Sahne üzerinde varolmak daha anlamlı bir şeye doğru dönüşümü beraberinde getirir. Bu dönüşümdeki anahtar sözcük, bir şeyin sergileniyor olmasıdır. Gösteri boyunca sergilenen her ayrıntı da gösterge durumuna gelir. ${ }^{1}$

Göstergebilimin tiyatroya girmesiyle birlikte tiyatro düşüncesi yeni boyutlar kazanmış, sahne ve metne yaklaşım değişikliğe uğramıştır. Sahne, metin ile gösterinin (temsilin) birleştiği bir göstergeler bütünü/ dizgesi olarak görülmeye ve ele alınmaya başlamıştır; sahneye koyma eylemi de "göstergeye dönüştürme" etkinliği olmuştur. ${ }^{2}$

Göstergebilimin ve dolayısıyla tiyatro göstergebilminin temel yapı taşını gösterge kavramı oluşturur. Saussure'un tanımlamasından yola çıkarak, tiyatroda gösterge, bir gösteren ile gösterilenden oluşan en küçük anlam birimi olarak tanımlanır. Tiyatroda kavram, yani anlam, sahnede bir imge aracılığıyla gösterilir. Pavis, tiyatro göstergesinin formülünün şu şekilde yazılabileceğini söyler:

Gösterge $=$ Gösteren $\{$ imge, görüntü $)+$ Gösterilen (Kavram, anlam) .

Gösteren sahnede kullanılan her şeydir: Nesne, renk, biçim, 1şık, mimik, hareket, devinim... Gösterilense kavramdır, gösterene yüklenen anlamdır, ya da oyunun, başka bir deyişle gösterinin ta kendisidir. ${ }^{3}$

Hem kendi başlarına var olan, hem de oyundaki eylemle ilişki içinde bulunan tiyatro göstergeleri, sahnede oluşturdukları bütün içinde tek başlarına değil, ancak öteki göstergelerle birlikte bir anlam kazanırlar. Bu anlam ise, bağlı bulundukları bütüne göre biçimlenir. Tek başına ele alınan bir nesne örneğin siyah bir giysi, birçok anlam taşıyabilir: Resmi elbise, kötü haber, ölüm, karamsarlık gibi. Bu nesnenin belirli bir anlama bağlı olarak işlev kazanması, kullanıldığı öteki öğelerle olan ilişkilerine göre gerçekleşir. Başka bir deyişle gösterge, öteki göstergelerle oluşturduğu bütün içinde bir anlam kazanır.

Özetlemek gerekirse, temel kavramlarını Ferdinand de Saussure'ün Genel Dilbilim Dersleri'nde dilsel olguların incelenmesi üzerine ortaya attığı düşüncelerden alan, Prag Okulu ve Rus Biçimselliğinin etkisiyle genel çerçevesi oluşan yapısalcılık, XX. yüzyıl insan bilimlerine "yapısalcılık çağı" adını verecek kadar tartışma gündemi yaratan bir yöntem olur. Yüzeydeki görüntünün altında, derinde yatan kuralların ve yasaların oluşturduğu yapıyı arayan bir yöntem olan yapısalcı yöntem, yapıyı oluşturan birimlerin tek başlarına anlam taşımadıklarını, yapı içinde birbirleriyle olan bağıntılardan anlam kazandıklarını savunur. Saussure'ün dili incelemek için herhangi bir dış

\footnotetext{
${ }^{1}$ Martin, Esslin. Dram Sanatının Alanı. (İstanbul: Yapı Kredi Yayınları, 1996), s.33, 44.

2 "Patrice, Pavis, Problémes de Semiologie Théatrale. (Quebec: Presses de I'Universite de Quebec, 1976), s. 137. Esen, Çamurdan. Cağgaș Tiyatro ve Dramaturgi. (istanbul: Mitosboyut Yayınları, 1996), s 38'deki alintı.

3 "Patrice Pavis. Dictionnaire du Theatre (Messidor / Editions Soriales, 1987)"

"Esen Çamurdan. Cağdaș Tiyatro ve Dramaturgi. (İstanbul: Mitosboyut Yayınları, 1996), s 39'daki alıntı.
} 
gerçekliğe başvurmaması, sistemin bir başka ifadeyle dizgenin, gerçeklikten bağımsız, kendi başına işleyen bir bütün olması bağlamındaki görüşleri ve bu görüşlerin izinden giden Todorov, Barthes ve Greimas gibi yapısalcıların da aynı biçimde yazarla, tarihle ya da metin dışı dünya ile yapıt arasında bağ kurmak gereğinden uzak yaklaşımları yöntemi tanımlar Ele alınan nesnenin "kendi başına ve kendi kendisi için" incelenmesi; nesnenin kendi öğeleri arasındaki bağıntılardan oluşan bir "dizge" olarak ele alınması; söz konusu dizge içinde her zaman işlevi göz önünde bulundurma ve her olguyu bağlı olduğu dizgeye dayandırma zorunluluğunun sonucu olarak, nesnenin artsüremlilik içinde değil, eşsüremlilik içinde ele alınması yapısalcı yöntemin temel ilkeleri olarak belirir. 


\section{Kaynakça}

Çamurdan, Esen. Çağdaş Tiyatro ve Dramaturgi. İstanbul: MitosBoyut Yayınları, 1996.

Esslin, Martin. Dram Sanatının Alanı. İstanbul: Yapı Kredi Yayınları, 1996.

Kıran, Zeynel. Dilbilim Akımları. Ankara: Onur Yayınları, 1996.

Lévi-Strauss, Claude. Yaban Düşünce. Çev.: Tahsin Yücel.İstanbul: Yapı Kredi Yayınları, 2002.

Moran, Berna. Edebiyat Kuramları ve Eleştiri. İstanbul: İletişim Yayınları, 2001.

Piaget, Jean. Yapısalcılık. Çev.:Ayşe Şirin Okyayuz Yener.Ankara: Doruk Yayınları, 1999.

Propp Vladimir. Masalın Biçimbilimi. Çev.: Mehmet Rifat, Sema Rifat.İstanbul: Om Yayınları, 2001.

Rifat, Mehmet. Göstergebilimcinin Kitabı. İstanbul: Düzlem Yayıncılık, 1996.

Rifat, Mehmet. XX. Yüzyılda Dilbilim ve Göstergebilim Kuramları "Tarihçe ve Eleştirel

Düşünceler”. İstanbul: Om Yayınevi, 2000.

Rifat, Mehmet. XX. Yüzyılda Dilbilim ve Göstergebilim Kuramları "Temel Kuramlar". İstanbul:Om Yayınevi, 2000.

Saussure de Ferdinand. Genel Dilbilim Dersleri. Çev.: Berke Vardar. İstanbul: Multilingual Yayınları, 1998.

Scholes, Robert. Structuralism in Literature.London: Yale University Press, 1974.

Yücel, Tahsin. Yapısalcılık.İstanbul. YapıKredi Yayınları, 1999.

Yüksel, Ayşegül. Yapısalcılık ve Bir Uygulama.Ankara: Gündoğan Yayınları, 1995. 